$\mathrm{DE}$

M E D I C I N A

T R O P I C A L

DE

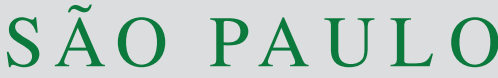

JOURNAL OF THE SÃO PAULO INSTITUTE OF TROPICAL MEDICINE

${ }^{1}$ Universidade Federal de Mato Grosso do Sul, Programa de Pós-Graduação em Doenças Infecciosas e Parasitárias, Campo Grande, Mato Grosso do Sul, Brazil

2Universidade Federal de Mato Grosso do Sul, Instituto de Biociências, Laboratório de Parasitologia Humana, Campo Grande, Mato Grosso do Sul, Brazil

${ }^{3}$ Universidade Federal da Grande Dourados, Programa de Pós-Graduação em Entomologia, Dourados, Mato Grosso do Sul, Brazil

${ }^{4}$ Universidade Federal de Mato Grosso do Sul, Instituto Integrado de Saúde, Campo Grande, Mato Grosso do Sul, Brazil

${ }^{5}$ Universidade Federal de Mato Grosso do Sul, Programa de Pós-Graduação em Ciências Veterinárias, Campo Grande, Mato Grosso do Sul, Brazil

Correspondence to: Alessandra Gutierrez de Oliveira

Universidade Federal de Mato Grosso do Sul, Instituto de Biociências, Laboratório de Parasitologia Humana, Av. Costa e Silva, s/n, Bairro Universitário, CEP 79070-900, Campo Grande, MS, Brazil

Tel: +55 67 3345-7369

E-mail: alessandra.oliveira@ufms.br

Received: 20 April 2018

Accepted: 9 January 2019

\section{Abiotic factors and population dynamic of Aedes aegypti and Aedes albopictus in an endemic area of dengue in Brazil}

\author{
Jeniffer Michelline de Oliveira Custódio', Livia Maria Serpa Nogueira², \\ Daiana Alovisi Souza², Magda Freitas Fernandes ${ }^{3}$, Elisa Teruya Oshiro², \\ Everton Falcão de Oliveira ${ }^{(1)}$, Eliane Mattos Piranda ${ }^{2,5}$, Alessandra Gutierrez \\ de Oliveira ${ }^{1,2}$
}

\section{ABSTRACT}

Aedes aegypti and Aedes albopictus are exotic species in the Americas with high epidemiological relevance as they are vectors of many pathogens. This study aimed at understanding the population dynamics of A. aegypti and A. albopictus and the influence of abiotic factors in an endemic area of dengue. The study was conducted in the urban area of Campo Grande, Mato Grosso do Sul, Brazil, over one year. In seven regions of the city, 50 ovitraps were installed in each neighborhood. The development of the larvae was monitored under controlled laboratory conditions until they reached the adult phase. A total of 50,900 eggs of Aedes sp. were collected, 26,073 of which reached adulthood: 25,496 (97.8\%) A. aegypti and $540(2.1 \%)$ A. albopictus. A. aegypti was observed in all months during the study. The highest number of $A$. albopictus eggs were collected in June, while in August and September, an absence of this species was noted. Abiotic factors such as temperature, humidity and rainfall were responsible for the observed fluctuations in the mosquito population. The presence of A. albopictus in the urban area of the city is concerning because it could become a potential vector for other arboviruses that afflict human populations. The occurrence of these species in Campo Grande reinforces the need for constant entomological and epidemiological surveillance so that informed actions could be taken to decrease potential breeding sites

KEYWORDS: Aedes sp. Entomological study. Infestation. Urban areas.

\section{INTRODUCTION}

Aedes aegypti (L.) and Aedes albopictus (Skuse) are exotic species to the American continents. They are vectors of several diseases such as yellow fever, chikungunya, zika, and dengue infections ${ }^{1}$.

These two species, A. aegypti and A. albopictus are mainly found in urban and peri-urban areas, respectively, and are closely related to the presence of blood sources and breeding sites.

According to Serpa et al. ${ }^{2}$ temperature, humidity, wind and rainfall are determinant factors that control the maintenance of these species and diseases. These climate variables can affect oviposition, viability of eggs, larval development, longevity and adults dispersion ${ }^{3}$.

In addition to the abiotic factors, Brazil as well as in other American countries, has macrodeterminant factors that help the proliferation of vectors and the transmission of diseases, such as inadequate sanitation conditions, little treatment and selective destination of waste, poor income distribution and low schooling of most population ${ }^{4}$. 
In Campo Grande, the capital of Mato Grosso do Sul (MS) State, 46,632 dengue cases were recorded, with the highest number of deaths, between 2011 and 20135. In 2017, the Brazilian Health Departament began to disclose epidemiological data of zika and chikungunya, newly introduced in the country. From 2015 to 2017 45,428 dengue cases, 5,525 zika cases and 555 chikungunya cases $^{6}$ were notified.

Although Campo Grande presents a high prevalence of dengue, there are no studies related to the behavior of these vectors in the urban area. Thus, we studied some aspects of these species population dynamics such as life cycle, female oviposition and density of eggs, as well as abiotic factors like pluviosity, rainfall and temperature that could influence these species in an endemic region of dengue.

\section{MATERIALS AND METHODS}

\section{Study area}

The municipality of Campo Grande covers 8,092.97 $\mathrm{km}^{2}$ and is located approximately in the center of MS State. The city has 74 neighborhoods divided into seven regions: Segredo, Prosa, Bandeira, Anhanduizinho, Lagoa, Imbirussu and Centro. The vegetation of Campo Grande is cerrado (Lato sensu), with clean fields of vegetation, cerradao (Stricto sensu) and ciliary forests ${ }^{7}$. According to the Köppen Climate Classification System, the climate is tropical savanna, subtype Aw, with two seasons: the dry season between April and September and the rainy season between October and $\mathrm{March}^{8}$. The average temperatures during these seasons are 15 and $24{ }^{\circ} \mathrm{C}$, respectively.

\section{Trap locations}

A. aegypti and A. albopictus eggs were collected monthly between May 2012 and April 2013. Ovitraps were randomly installed in 50 dwellings in each of the following neighborhoods (respective regions are in parentheses): Moreninha (Bandeira), Jardim Santa Emilia (Lagoa), Vila Carvalho (Centro), Jardim do Ze Pereira (Imbirussu), Pioneiros (Anhanduizinho), Vila Nasser (Segredo), and Novos Estados (Prosa). The traps were placed monthly and remained in the dwellings for a week.

The traps in the residences were installed according to standards established by the Technical Department of Entomology, Health Surveillance Secretariat, Ministry of Health. Traps were placed in in calm locations, away from people and animals, near breeding sites and potential domestic shelters, such as water tanks, potted plants and tanks, preferably at heights between 0.8 and 1.2 meters $^{9}$.
Monitoring the development of immature forms in the laboratory

The wooden pallets brought from the field were stored in polystyrene boxes until eggs counting. Eggs were placed in plastic boxes with natural water to monitor the development of immature stages, as proposed by Beserra et al. ${ }^{10}$ Daily larvae were counted and fed with fish food (Alcon Basic ${ }^{\circledR}$ ). The pupae were transferred into plastic jars with a fabric across the surface in order to promote air circulation and avoid dispersion of winged animals. Emerged adults were identified based on the taxonomic key according to Consoli and Oliveira ${ }^{11}$. Immature forms were developed in the laboratory at an average room temperature of $24.3^{\circ} \mathrm{C}$ and relative humidity of $62 \%$.

\section{Analysis of abiotic factors}

Temperature, humidity, rainfall and wind speed data were obtained from the Campo Grande A702 autonomous weather station maintained by the National Institute of Meteorology (INMET) $)^{12}$.

\section{Data analysis}

The ovitrap positivity index (POI) and egg density index (EDI) were obtained following the criteria established by Gomes $^{13}$.

The association between climate variables and the number of eggs and larvae collected were analyzed using Spearman's correlation. The number of positive ovitraps, mean eggs per trap (MET), male/female ratio and internal/ external temperature were analyzed using the Student's $t$-test. The developmental time of immature forms was calculated using descriptive statistics (mean and standard deviation).

\section{RESULTS}

From a total of 4,200 placed traps, Aedes sp. was observed in 1,529 wooden pallets: 1,475 with Ae. aegypti, 9 with Aedes albopictus and 45 with both species. The POI and EDI values found were of 36.4 and 32.0, respectively. The remaining pallets were negative for egg counting. The eggs were present in all months of the year, with variations in quantity depending on the trap location and time of the year.

The numbers of positive ovitraps in the dry and rainy seasons were 621 and 908, with 20,298 and 30,602 eggs, respectively. There was no significant difference in positivity between periods $(p>0,001)$ (Table 1$)$. 
Table 1 - Average positive ovitrap index (POI), egg density index (EDI), pre-hatching and hatching larvae according to the season (dry or rainy), Campo Grande, MS, May, 2012 to April, 2013.

\begin{tabular}{lcccc}
\hline Season & POI & EDI & Period & Larvae hatched \\
& $\mathrm{X} \pm \mathrm{SD}$ & $\mathrm{X} \pm \mathrm{SD}$ & pre-hatching & $\mathrm{XD}(\%)$ \\
\hline Dry & $29.6 \pm 7.3$ & $28.8 \pm 26.5$ & $1-6$ days & $2431.0 \pm 29.4(49.3 \%)$ \\
Rainy & $43.2 \pm 12.8$ & $34.8 \pm 15.5$ & $1-5$ days & $2363.5 \pm 21.5(50.7 \%)$ \\
\hline Total (year) & $36.4 \pm 19.7$ & $32.0 \pm 27.9$ & $1-6$ days & $2397.2 \pm 25.8(56.5 \%)$ \\
\hline
\end{tabular}

$\mathrm{X} \pm \mathrm{SD}=$ standard deviation

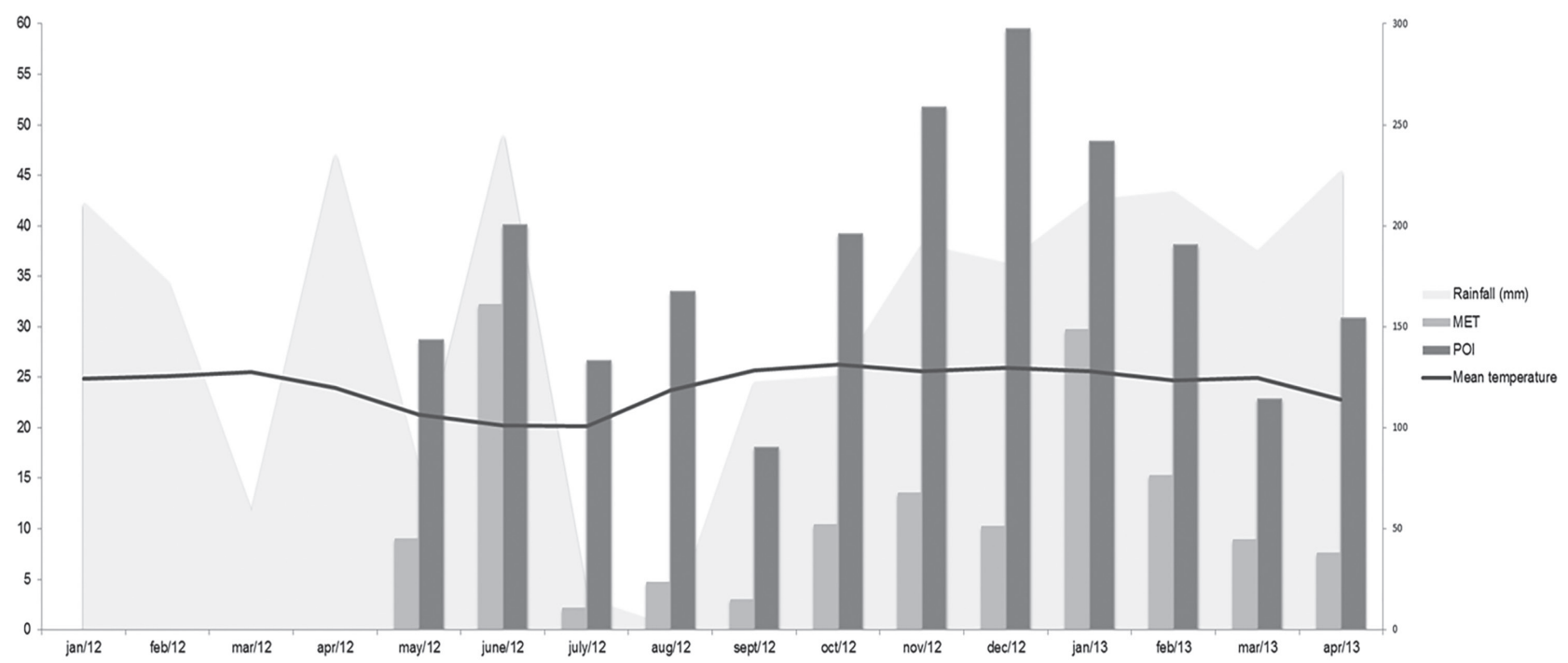

Figure 1 - Monthly distribution of positive ovitrap index (POI), mean egg counts per trap (MET), rainfall and mean temperature, Campo Grande, MS, May/2012 to April/2013.

The mean eggs per trap (MET) was 3,383 for the dry season and 5,100 for the rainy season $(p<0.001)$ (Figure 1$)$.

Climate factors influencing oviposition and larvae hatching were temperature, humidity and rainfall $(p<0.05)$ (Table 2). There were no differences between internal and external laboratory temperature $(t=0.5396, \mathrm{GL}=19.008$, $p=0.6)$ and humidity $(t=-0.7771, \mathrm{GL}=17.234, p=0.4)$.

Table 2 - Correlation coefficients between the total number of eggs and larvae, and climate variables, Campo Grande, MS, May, 2012 to April, 2013.

\begin{tabular}{lccc}
\hline Phase & $\begin{array}{c}\text { Average } \\
\text { temperature }\left({ }^{\circ} \mathrm{C}\right)\end{array}$ & $\begin{array}{c}\text { Relative } \\
\text { humidity }(\%)\end{array}$ & $\begin{array}{c}\text { Precipitation } \\
\text { rainfall }(\mathrm{mm})\end{array}$ \\
\hline Eggs & 0.17 & $0.57^{*}$ & $0.70^{*}$ \\
Larvae & $-0.26^{*}$ & - & $0.71^{*}$ \\
\hline${ }^{*} p<0.05$ & & &
\end{tabular}

From a total of 50,900 collected eggs, 9,322 larvae hatched during transportation from the field. Therefore, 41,578 eggs were viable for further analysis in the laboratory. The development of immature stages lasted on average 9.4 days, varying between 5 and 42 days as shown in Table 3, the highest mortality numbers occurred in egg and L2 stages.

A total of 41,578 eggs belonging to both, A. aegypti and A. albopictus were collected; among them 28,767 completed the larval stage and 26,073 reached adulthood (Table 4). Among those who reached adulthood, 25,496 (97.8\%) were identified as A. aegypti, $540(2.0 \%)$ as A. albopictus, and $37(0.2 \%)$ were not identified due to morphological issues. From the 26,073 specimens, 25,433 were not sexed: (1) 37 specimens could not be identified; (2) it was not possible to sex 603 specimens of $A$. aegypti due to loss of important sexing structures. The overall ratio of males to females was 1.01 for A. aegypti and 0.69 for A. albopictus. These results are presented in Table 5. There was no statistical difference between the number of males and females.

The presence of $A$. aegypti was observed in every month of the year, whilst that of A. albopictus was not observed in August, September and April (Figure 2). Regarding location, the highest numbers of A. aegypti and A. albopictus were recorded in Pioneiros and Novos Estados. A. albopictus was absent in Moreninha. 
Table 3 - Duration in days, mean, median and mortality of eggs and Aedes sp. immature stages under laboratory conditions, Campo Grande, MS, May, 2012 to April, 2013.

\begin{tabular}{|c|c|c|c|c|}
\hline Stages (N) & Amplitude & Mean & Median & Mortality (\%) \\
\hline Eggs $(41,578)$ & - & - & - & 30.81 \\
\hline L1 $(28,767)$ & $1-7$ & 1.3 & 1 & 1.62 \\
\hline L2 $(28,300)$ & $1-13$ & 1.6 & 1 & 4.34 \\
\hline L3 $(27,071)$ & $1-31$ & 3.0 & 2 & 1.57 \\
\hline L4 $(26,647)$ & $1-39$ & 6.3 & 4 & 2.11 \\
\hline Pupa $(26,085)$ & $1-38$ & 5.5 & 4 & 0.05 \\
\hline Total & 5 & 9.4 & 8 & 40.50 \\
\hline
\end{tabular}

Table 4 - Absolute frequency, mean and standard deviation of eggs, larvae and adults according to the neighborhood, Campo Grande, MS, May, 2012 to April, 2013.

\begin{tabular}{|c|c|c|c|c|c|c|c|c|c|}
\hline \multirow{2}{*}{ Neighborhood } & \multicolumn{3}{|c|}{ Eggs } & \multicolumn{3}{|c|}{ Larvae hatched } & \multicolumn{3}{|c|}{ Adults } \\
\hline & $\mathrm{N}$ & Mean & SD & $\mathrm{N}$ & Mean & SD & $\mathrm{N}$ & Mean & SD \\
\hline Moreninha & 3,913 & 6.5 & 16.8 & 2,669 & 4.5 & 12.9 & 2,426 & 4.0 & 11.9 \\
\hline Jardim Santa Emília & 3,170 & 5.3 & 14.3 & 2,172 & 3.6 & 11.1 & 2,010 & 3.4 & 10.6 \\
\hline Vila Carvalho & 5,598 & 9.3 & 24.4 & 4,287 & 7.2 & 20.7 & 4,047 & 6.8 & 20.2 \\
\hline Jardim do Zé Pereira & 6,925 & 11.5 & 29.5 & 4,011 & 6.7 & 20.3 & 3,601 & 6.0 & 19.0 \\
\hline Pioneiros & 12,083 & 20.1 & 50.8 & 9,201 & 15.3 & 43.6 & 8,372 & 14.0 & 39.2 \\
\hline Vila Nasser & 4,781 & 8.0 & 23.4 & 2,751 & 4.6 & 15.2 & 2,523 & 4.2 & 13.9 \\
\hline Novos Estados & 5,108 & 8.5 & 27.6 & 3,676 & 6.1 & 23.1 & 3,094 & 5.2 & 20.5 \\
\hline Total & 41,578 & 9.8 & 29.2 & 28,767 & 6.9 & 23.6 & 26,073 & 6.2 & 21.56 \\
\hline
\end{tabular}

$\mathrm{N}=$ absolute frequency; $\mathrm{X} \pm \mathrm{SD}=$ Standard deviation.

Table 5 - Number of male and female adults and male/female ratio for Ae. aegypti and Ae. albopictus in the neighborhood of Campo Grande, MS, May, 2012 to April, 2013 ( $n=25,433)$.

\begin{tabular}{|c|c|c|c|c|c|c|c|c|}
\hline Neighborhood & $\begin{array}{l}\text { Aedes } \\
\text { aegypti }\end{array}$ & $\hat{0}$ & q & $\begin{array}{c}\text { Ratio } \\
\text { (male/female) }\end{array}$ & $\begin{array}{c}\text { Aedes } \\
\text { albopictus }\end{array}$ & $\hat{0}$ & q & $\begin{array}{c}\text { Ratio } \\
\text { (male/female) }\end{array}$ \\
\hline Moreninha & 2,348 & 1,166 & 1,182 & 0.98 & 0 & 0 & 0 & 0.00 \\
\hline Jardim Santa Emilia & 1,850 & 995 & 855 & 1.16 & 40 & 16 & 24 & 0.66 \\
\hline Vila Carvalho & 4,021 & 2,042 & 1,979 & 1.03 & 7 & 4 & 3 & 1.33 \\
\hline Jardim do Ze Pereira & 3,239 & 1,560 & 1,679 & 0.92 & 62 & 36 & 26 & 1.38 \\
\hline Pioneiros & 8,286 & 4,148 & 4,138 & 1.00 & 11 & 7 & 4 & 1.75 \\
\hline Vila Nasser & 2,327 & 1,247 & 1,080 & 1.15 & 179 & 81 & 98 & 0.82 \\
\hline Novos Estados & 2,822 & 1,394 & 1,428 & 0.97 & 241 & 78 & 163 & 0.47 \\
\hline Total & 24,893 & 12,552 & 12,341 & 1.01 & 540 & 222 & 318 & 0.69 \\
\hline
\end{tabular}

${ }^{*} p<0.05$

\section{DISCUSSION}

The utilization of ovitraps allowed us to verify the infestation of Aedes sp. According to Vargas ${ }^{14}$, this method can identify culicids even at low densities, with the advantage of being inexpensive and effective for vector surveillance. In this study, the technique was sensitive enough to detect a reduced amount of eggs during the cold and dry months. The ability to detect the presence of Aedes sp. in unfavorable climate conditions shows the necessity of continuous surveillance.

The infestation rate of $36.4 \%$ and the mean of 32 eggs 


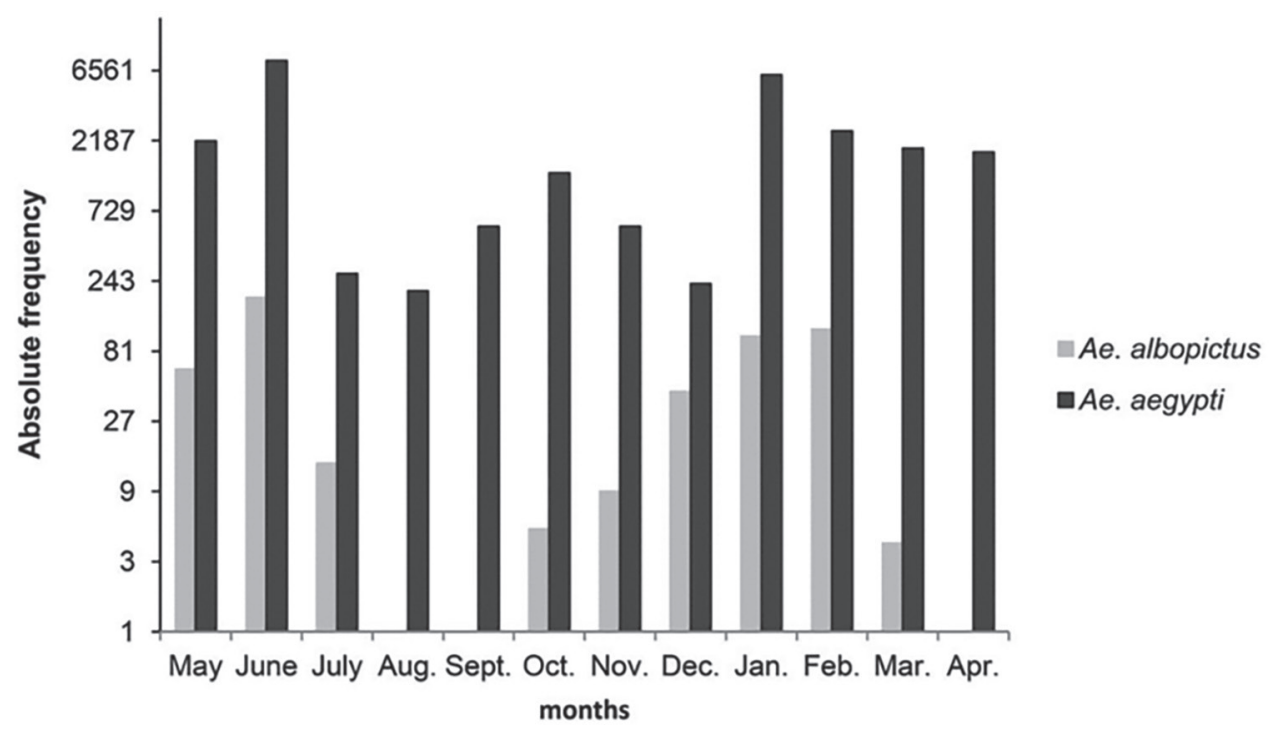

Figure 2 - Monthly distribution of Aedes aegypti and Aedes albopictus in Campo Grande, MS, May/2012 to April/2013.

per trap allowed an indirect measurement of the abundance of females in the environment ${ }^{15}$. Previous studies have reported similar results with respect to $\mathrm{POI}^{16}$. However, if the trap exposure time is longer, both, POI and EDI are higher, independent of the period of the year ${ }^{15}$.

Ribeiro et al. ${ }^{17}$ stated that abiotic factors, especially rainfall, affects survival, reproduction and causes changes in vectors distribution and density. In the present study, a higher number of positive ovitraps were detected in the rainy season when compared to the dry season, however, the difference was not statistically significant. Regis et al. ${ }^{15}$ also found a greater abundance of these dipterans during the rainy season. According to Carvalho et al. ${ }^{18}$ the increase in the density of mosquitoes during this period is associated with large amounts of water deposits and abundant natural breeding sites.

For all sampled neighborhoods, the presence of females in reproductive phase was observed, with variations among collection sites. The greatest positivity of ovitraps and egg density occurred in Pioneiros neighborhood, which is a region of the city with a high population density. Barata et $a l .{ }^{19}$ reported a higher number of females in sites that shared similar characteristics, such as the diversity of artificial breeding sites, suggesting that these places could provide favorable conditions for A. aegypti proliferation. Conversely, in the two neighborhoods, Moreninha and Jardim Santa Emilia, which present a high population density, low values of ovitrap positivity were found. This could be explained by the low density of insects or the absence of viable breeding sites inside and around dwellings ${ }^{20}$. Another relevant fact is that these neighborhoods are old and their residents have lived there for long periods of time so that a greater adherence to vector control measures might have occurred ${ }^{7}$.
In the present study, a greater egg loss and a lower larval yield were observed. During the activities performed in the field, an increase in eggs with hatched larvae was observed in rainy months. On the other hand, high mortality frequencies of dried eggs were detected in periods of low humidity. According to Farnesi et al. ${ }^{21}$ the composition of the eggshell and the presence of the serosa cuticle are likely to be responsible for eggs viability and resistance to desiccation. Non-embryonated eggs do not present rapid and uniform development when in contact with water mainly when dried within $24 \mathrm{~h}$ of laying and are therefore kept for a few days. This could be an explanation for the change in embryonic development observed in the month of August when humidity was low; this was studied by Shannon and Putnam $^{22}$, who claimed that moisture is necessary for the development of the first larva inside the egg and once it reaches maturity, becomes sensitive to certain stimuli that trigger the hatching.

The daily monitoring of immature forms in the laboratory have also revealed a significant association with climate variables. The development cycle of larvae and pupae varied from 5 to 42 days, with an average of 9.4 days at $24.3{ }^{\circ} \mathrm{C}$ and $62 \%$ relative humidity. It was possible to observe fluctuations in the duration of the cycle, mainly in the rainy season. This period is characterized by high temperatures and relative humidity and the development cycles during this period were reduced in time. The period from larva hatching to pupa formation for A. aegypti was 5 to 14 days under ideal temperature and food availability ${ }^{23}$. An interesting fact occurred in June, in which there was an unusually high amount of precipitation and relative humidity, but low temperatures. Over this period, the larval development period extended up to 42 days. A study 
from Ferreira and Yang ${ }^{24}$ have also demonstrated that the environment temperature and the relative humidity are determinant factors in the development of the mosquito.

The mean development time for stages L4 and pupa were 6.3 and 5.4 days, respectively. These results were higher than those presented by Silva et al. ${ }^{25}$ who obtained averages of between 2.4 and 3.8 days for $\mathrm{L} 4$ and between 1.8 and 2.3 days for pupae. These differences in cycle length might be related to the mean laboratory temperature of $24.3{ }^{\circ} \mathrm{C}$ in the present study, which was up to four degrees lower than the literature findings.

The effect of temperature on larval development indicates that this variable is indirectly related to the mean duration of larval stage; that is, the increase in temperature reduces the duration of development of all immature stages, which in turn reduces its cycle ${ }^{26}$. However, Consoli and Oliveira ${ }^{11}$ claim that the ideal temperature for all mosquito life cycle stages is the one in which the development occurs with the lowest mortality rate.

In addition, several studies have shown that fluctuations in temperature might alter Anopheles sp. and Aedes sp. ${ }^{27}$ vector competence. A reduced competence of $A$. aegypti for Flavivirus has already been reported in temperatures above $18^{\circ} \mathrm{C}$; however, dengue virus (DENV) transmission increased at lower temperatures ${ }^{28}$.

An increase in the cycle duration of immatures was observed in ovitraps that were full of eggs. This subject has been addressed by Costa et al. ${ }^{29}$ who hypothesized that stage lengths could be regulated by a high larvae population density. There was a large capture of eggs in June and the hatched larvae were kept in high density possibly influencing the cycle duration. Gama et al. ${ }^{30}$ stated that when larvae are subjected to overpopulation and a shortage of food, their development is compromised and, as a result, mortality increases.

Cohabitation of species was observed in the city of Campo Grande. Forty-five wooden pallets were positive for both, A. aegypti and A. albopictus, however the first one was the most prevalent. This fact is associated with the capacity of these species to live in urban environments ${ }^{31,32}$. A. aegypti was observed in all months of this study with a high frequency, supporting its predominance in relation to A. albopictus. Although A. aegypti is resistant to low humidity, a reduction in the frequency of specimens was observed during the dry season; this finding was previously reported by Serpa et al. ${ }^{33}$ regarding the the months of July, August and September. Forattini and Brito ${ }^{34}$ consider domestic reservoirs as key factors in sustaining $A$. aegypti populations during periods of low rainfall.

The process of urbanization has substantially increased Ae. albopictus density, larval development rate and adult survival time in the cities, and can be frequently found to share breeding sites with $A$. aegypti ${ }^{35,36}$. Almeida et al. ${ }^{37}$ observed a predominance of A. albopictus in relation to A. aegypti in the municipality of Dourados, MS. According to Passos et al..$^{38}$ the expansion of A. albopictus is causally related to the type of habitat; due to its zoophilic nature, this species develops preferentially in wild environments and places with low population densities. The adoption of new breeding sites could be a consequence of diminished resources and the more these resources are depleted, the higher the probability of intraspecific competition, or rather, population dislocation to seek out habitats that are more viable $^{35}$. It is believed that the introduction of A. albopictus in Campo Grande is recent, since this species has been found in fewer numbers. It is known that this species prefer wild habitats, but the rapid expansion of urban areas has changed natural ecotopes so that A. albopictus have moved to anthropophilic areas ${ }^{35}$.

The greatest density of A. albopictus was observed during the months of June and January, while the species was absent during August, September, and April. The suppression of this species during August and September can be explained by intense drought, while the absence in April is most likely due to vector control actions that caused a higher mortality of A. albopictus than of A. aegypti. The fact that A. albopictus was not continuously present indicates that this species is sensitive to abiotic factors ${ }^{39}$. Forattini et al..$^{40}$ found a higher infestation of this species in Ilha Comprida, Sao Paulo (SP), during months of greater rainfall, supporting the idea that $A$. albopictus is sensitive to abiotic factors.

A. albopictus was more prevalent in the Novos Estados neighborhood, which according to the urban planning department of Campo Grande presents a low population density. On the other hand, this species was not found in the Moreninha neighborhood, which is a highly populated region with consolidated urban development and absence of vegetation. Thus, even though A. albopictus prefers wild habitats, its recording in residential areas denotes an adaptation to urban environments.

In our study, the sexual ratio of $A$. aegypti was as expected, suggesting the population development stability. The balance between males and females has probably occurred due to the constant temperature $\left(24.3{ }^{\circ} \mathrm{C}\right)$ in most months. However, other studies with A. aegypti have shown uneven proportions, with prevalence of males ${ }^{41}$. This prevalence was suggested by Craig et al. ${ }^{42}$ to be a hereditary trait in certain lineages and single-pair progenies of A. aegypti. Under laboratory conditions, Tun-lin et $a l .{ }^{43}$ studied the effect of temperature and larval diet on A. aegypti sexual ratio. They detected a predominance 
of females at a temperature of $30^{\circ} \mathrm{C}$, and homogeneity at temperatures of $15,20,25$ and $35^{\circ} \mathrm{C}$, suggesting an influence of temperature on the species sexual ratio. Silva and Silva ${ }^{44}$ have also reported a balanced sexual proportion in this species at $28^{\circ} \mathrm{C}$.

In the present study, A. albopictus male/female ratio was not significantly different. In a study conducted in Sao Paulo State, Forattini et al. ${ }^{40}$ found a greater abundance of females of this species. Yet, Briegel and Timmermann ${ }^{45}$ studying larvae of A. albopictus under laboratorial conditions of temperatures between 12 and $32{ }^{\circ} \mathrm{C}$, observed a male/female ratio of 2:1. In Parana State Fantinatti et al..$^{46}$ have also described a 1:1 ratio for $A$. aegypti and a higher number of A. albopictus males.

A higher ratio of females may increase the number of oviposition and/or affect competition among males. Either way, there might be a significant effect on the composition of the following generations due to a reduced genetic variability. Nevertheless, the similar proportion between males and females observed for Campo Grande may indicate a balance and intraspecific adaptation.

The results found in the present study suggest that an entomologic surveillance program must be conducted continuously, not only during the rainy season ${ }^{47}$. There was a prevalence of $A$. aegypti, which demonstrated a greater ability of this species to colonize residences. The presence of A. albopictus in the urban area of the city is concerning because it could become a potential vector of other arboviruses to human populations. The recording of these species in Campo Grande, MS, reinforces the need of constant entomological and epidemiological surveillance to decrease potential breeding sites.

\section{CONFLICT OF INTERESTS}

The authors declare that they have no conflict of interests.

\section{ACKNOWLEDGMENTS}

The authors thank Elaine Araújo e Silva and her staff from the Zoonosis Control Center of Campo Grande for their support in the captures; the residents for authorizing the installation of traps and all the staff of the Laboratory of Parasitology - UFMS.

\section{FINANCIAL SUPPORT}

This study was financed in part by the Coordenação de Aperfeiçoamento de Pessoal de Nível Superior - Brasil (CAPES) - Finance Code 001.

\section{REFERENCES}

1. Honório NA, Câmara DC, Calvet GA, Brasil P. Chikungunya: an arbovirus infection in the process of establishment and expansion in Brazil. Cad Saude Publica. 2015;31:906-8.

2. Serpa LL, Marques GR, Lima AP, Voltolini JC, Arduino MB, Barbosa GL, et al. Study of the distribution and abundance of the eggs of Aedes aegypti and Aedes albopictus according to the habitat and meteorological variables, municipality of São Sebastião, São Paulo State, Brazil. Parasit Vectors. 2013;6:321.

3. Rodrigues MM, Marques GR, Serpa LL, Arduino MB, Voltolini JC, Barbosa GL, et al. Density of Aedes aegypti and Aedes albopictus and its association with number of residents and meteorological variables in the home environment of dengue endemic area, São Paulo, Brazil. Parasit Vectors. 2015;8:115.

4. Coelho GE. Dengue: desafios atuais. Epidemiol Serv Saude. 2008; 17:231-3

5. Brasil. Ministério da Saúde.Boletim epidemiológico $\mathrm{N}^{\circ} 39$ : dengue: semana 52 - Mato Grosso do Sul. [cited 2019 Jan 22]. Available from: http://www.sgvs.saude.ms.gov. br/wp-content/uploads/sites/101/2018/01/BOLETIMEPIDEMIOL\%C3\%93GICO-DENGUE.pdf

6. Campo Grande. Secretaria Municipal de Saúde Pública. Boletim epidemiológico - Dengue, Zika e Chikungunya (2018/01). [cited 2018 Dec 11]. Available from: http://www.campogrande. ms.gov.br/sesau/downloads/boletim-epidemiologico-denguezika-e-chikungunya-201801/

7. Campo Grande. Agência Municipal de Meio Ambiente e Planejamento Urbano. Perfil socioeconômico de Campo Grande: Mato Grosso do Sul. 25 ${ }^{\mathrm{a}}$ ed. Campo Grande: PLANURB; 2018. [cited 2018 Oct 22]. Available from: http:// www.campogrande.ms.gov.br/planurb/downloads/perfilsocioeconomico-25a-edicao-revista-2018/

8. Rohli RV, Vega AJ. Climatology. Boston: Jones and Bartlett; 2008.

9. Santa Catarina. Secretaria de Estado da Saúde. Superintendência de Vigilância em Saúde. Diretoria de Vigilância Epidemiológica. Vigilância e controle do Aedes aegypti: orientações técnicas para pessoal de campo. Santa Catarina: DIVE; 2018. [cited 2018 Aug 29]. Available from: http://www.dive.sc.gov.br/ conteudos/publicacoes/ManualDengue2018.pdf

10. Beserra EB, Castro Jr FP, Santos JW, Santos TS, Fernandes CR. Biologia e exigências térmicas de Aedes aegypti (L.) (Diptera: Culicidae) provenientes de quatro regiões bioclimáticas da Paraíba. Neotrop Entomol. 2006;35:853-60.

11. Consoli RA, Oliveira RL. Principais mosquitos de importância sanitária no Brasil. Rio de Janeiro: Fiocruz; 1994.

12. Centro de Monitoramento de Tempo, do Clima e dos Recursos Hídricos de Mato Grosso do Sul. Banco de dados. [cited 2019 Jan 22]. Available from: http://www.cemtec.ms.gov. br/?page_id=15 
13. Gomes AC. Vigilância entomológica. Inf Epidemiol SUS 2002;11:79-90.

14. Vargas M. Uso de ovitrampas en los programas de prevención y control del dengue. Rev Col MQC Costa Rica. 2002;8:122-4.

15. Regis L, Monteiro AM, Melo-Santos MA, Silveira Jr JC, Furtado AF, Acioli RV, et al. Developing new approaches for detecting and preventing Aedes aegypti population outbreaks: basis for surveillance, alert and control system. Mem Inst Oswaldo Cruz. 2008;103:50-9.

16. Campos M, Spenassatto C, Macoris ML, Paduan KS, Pinto J, Ribolla PE. Seasonal population dynamics and the genetic structure of the mosquito vector Aedes aegypti in São Paulo, Brazil. Ecol Evol. 2012;2:2794-02.

17. Ribeiro AF, Marques GR, Voltolini JC, Condino ML. Associação entre incidência de dengue e variáveis climáticas. Rev Saude Publica. 2006;40:671-6.

18. Carvalho MS, Caldas ED, Degallier N, Vilarinhos PT, Souza LC, Yoshizawa MA, et al. Suscetibilidade de larvas de Aedes aegypti ao inseticida temefós no Distrito Federal. Rev Saude Publica. 2004;38:623-9.

19. Barata EA, Costa AI, Chiaravalloti Neto F, Glasser CM, Barata JM, Natal D. População de Aedes aegypti (1.) em área endêmica de dengue, Sudeste do Brasil. Rev Saude Publica. 2004;35:23742 .

20. Nunes LS Trindade RB, Souto RN. Avaliação da atratividade de ovitrampas a Aedes (Stegomyia) aegypti Linnaeus (Diptera: Culicidae) no bairro Hospitalidade, Santana, Amapá. Biota Amazonia. 2011;1:26-31.

21. Farnesi LC, Brito JM, Linss JG, Pelajo-Machado M, Valle D, Rezende GL. Physiological and morphological aspects of Aedes aegypti developing larvae: effects of the chitin synthesis inhibitor novaluron. PLoS One. 2012;7:e30363.

22. Shannon RC, Putnam P. Biology of Stegomyia under laboratory conditions : I. The analysis of factors which influence larval development. Proc Entomol Soc Wash. 1934;36:185-216.

23. Aldama PC, Garcia FJ, Esquivel RC. Ciclo de vida del Aedes aegypti y manifestaciones clínicas del dengue. Acta Pediatr Mex. 2001;22:114-17.

24. Ferreira CP, Yang HM. Estudo dinâmico da população de mosquitos Aedes aegypti. Tend Mat Apl Comput. 2003;4:18796.

25. Silva HH, Silva IG, Lira KS. Metodologia de criação, manutenção de adultos e estocagem de ovos de Aedes aegypti (Linnaeus, 1762) em laboratório. Rev Patol Trop. 1998;27:53-63.

26. Calado DC, Silva MA. Avaliação da influência da temperatura sobre o desenvolvimento de Aedes albopictus. Rev Saude Publica. 2002;36:173-9.

27. Carrington LB, Armijos MV, Lambrechts L, Barker CM, Scott TW. Effects of fluctuating daily temperatures at critical thermal extremes on Aedes aegypti life-history traits. PLoS One. 2013;8:e58824.
28. Lambrechts L, Paaijmans KP, Fansiri T, Carrington LB, Kramer LD, Thomas MB, et al. Impact of daily temperature fluctuating on dengue virus transmission by Aedes aegypti. Proc Natl Acad Sci USA. 2011;108:7460-5.

29. Costa FS, Silva JJ, Souza CM, Mendes J. Dinâmica populacional de Aedes aegypti (L) em área urbana de alta incidência de dengue. Rev Soc Bras Med Trop. 2008;41:309-12.

30. Gama RA, Alves KC, Martins RF, Eiras AE, Resende MC. Efeito da densidade larval no tamanho de adultos de Aedes aegypti criados em condições de laboratório. Rev Soc Bras Med Trop. 2005;38:64-6.

31. Lounibos LP, Kramer LD. Invasiveness of Aedes aegypti and Aedes albopictus and vectorial capacity for chikungunya virus. J Infect Dis. 2016;214 Suppl 5:S453-8.

32. Konan YL, Coulibaly ZI, Koné AB, Ekra KD, Doannio JM, Dosso M, et al. Species composition and population dynamics of Aedes mosquitoes, potential vectors of arboviruses, at the container terminal of the autonomous port of Abidjan, Côte d'Ivoire. Parasite. 2013;20:13-9.

33. Serpa LL, Costa KV, Voltolini JC, Kakitani I. Variação sazonal de Aedes aegypti e Aedes albopictus no município de Potim. Rev Saude Publica. 2006;40:1101-5.

34. Forattini OP, Brito M. Reservatórios domiciliares de água e controle do Aedes aegypti. Rev Saude Publica. 2003;37:676-7.

35. Glasser CM, Gomes AC. Clima e sobreposição da distribuição de Aedes aegypti e Aedes albopictus na infestação do Estado de São Paulo. Rev Saude Publica. 2002;36:166-72.

36. Li Y, Kamara F, Zhou G, Puthiyakunnon S, Li C, Liu Y, et al. Urbanization increases Aedes albopictus larval habitats and accelerates mosquito development and survivorship. PLoS Negl Trop Dis. 2014;8:e3301.

37. Almeida PS, Ferreira AD, Pereira VL, Fernandes MG, Fernandes WD. Distribuição espacial de Aedes albopictus na região sul do Estado de Mato Grosso do Sul. Rev Saude Publica. 2006;40:1094-100.

38. Passos RA, Marques GR, Voltolini JC, Condino ML. Dominância de Aedes aegypti sobre Aedes albopictus no litoral sudeste do Brasil. Rev Saude Publica. 2003;37:729-34.

39. Honório NA, Castro MG, Barros FS, Magalhães MA, Sabroza PC. The spatial distribution of Aedes aegypti and Aedes albopictus in a transition zone, Rio de Janeiro, Brazil. Cad Saude Publica. 2009;25:1203-14.

40. Forattini OP, Kakitani I, Santos RL, Kobayashi KM, Ueno HM, Fernandez Z. Comportamento de Aedes albopictus e de Ae. scapularis adultos (Diptera: Culicidae) no Sudeste do Brasil. Rev Saude Publica. 2000;34:461-7.

41. Hickey WA, Craig GB Jr. Genetic distortion of sex ratio in a mosquito, Aedes aegypti. Genetics. 1966;53:1177-96.

42. Craig GB Jr, Vandehey RC, Hickey WA. Genetic variability in populations of Aedes aegypti. Bull World Health Organ. 1961;24:527-39. 
43. Tun-Lin W, Brukot TR, Kay BH. Effects of temperature and larval diet on development rates survival of the dengue vector Aedes aegypti in north queensland, Australia. Med Vet Entomol. 2000;14:31-7.

44. Silva HH, Silva IG. Influência do período de quiescência dos ovos sobre o ciclo de vida de Aedes aegypti (Linnaeus, 1762) (Diptera, Culicidae) em condições de laboratório. Rev Soc Bras Med Trop. 1999;32:349-55.
45. Briegel H, Timmermann SE. Aedes albopictus (Diptera: Culicidae): physiological aspects of development and reproduction. J Med Entomol. 2001;38:566-71.

46. Fantinatti EC, Duque JE, Silva AM, Navarro-Silva MA. Abundância e agregação de ovos de Aedes aegypti L. e Aedes albopictus (Skuse)(Diptera: Culicidae) no Norte e Noroeste do Paraná. Neotrop Entomol. 2007;36:960-5.

47. Lenzi MF, Coura LC. Prevenção da dengue: a informação em foco. Rev Soc Bras Med Trop, 2004;37:343-50. 